\title{
Biblijne podstawy nauczania o Duchu Świętym w Katechezach Cyryla Jerozolimskiego
}

\author{
The Biblical Basis for the Teachings about the Holy Spirit \\ in the Catecheses of Cyril of Jerusalem
}

\author{
NORBERT WIDOK \\ Uniwersytet Opolski \\ nwidok@uni.opole.pl, ORCID ID: 0000-0001-6829-2933
}

\begin{abstract}
Streszczenie: Tekst przedłożonego artykułu przedstawia nauczanie Cyryla Jerozolimskiego († 387) na temat Ducha Świętego w ramach jego interpretacji tzw. symbolu wiary stosowanego w Jerozolimie. Będąc autorem 18 katechez wygłoszonych do katechumenów i 5 skierowanych do neofitów, dwie z nich poświęcił przekazaniu nauki o Duchu Świętym. Są nimi Katecheza XVI i Katecheza XVII umieszczone w cyklu nauk katechetycznych przeznaczonych dla katechumenów. Analiza tekstowa tych katechez doprowadziła do wyselekcjonowania kilku aspektów tego nauczania, mającego charakter biblijnego udokumentowania przekazywanych wątków. Na uwagę zasługują kwestie związane z nazwami Ducha Świętego, $z$ istotą trynitarnych relacji oraz Jego naturą i zbawczymi zadaniami. Poszczególne zagadnienia, jak wykazała analiza, ukazują Cyryla jako wytrawnego teologa i katechetę drugiej połowy IV wieku, a więc przez Soborem Konstantynopolitańskim, na którym dopiero została rozstrzygnięta nauka o Duchu Świętym w spisanym tam Credo.
\end{abstract}

Słowa kluczowe: Cyryl Jerozolimski; symbol wiary; Duch Święty; katechezy katechumenalne; przekaz biblijny

\begin{abstract}
The following article presents the teaching of Cyril of Jerusalem (†387) about the Holy Spirit as part of his interpretation of the so-called symbol of faith used in Jerusalem. Being the author of 18 catecheses delivered to the catechumens, and 5 others addressed to neophytes, he devoted two of them to teachings about the Holy Spirit. These are Catechesis XVI and Catechesis XVII included in the catechetical series for catechumens. Textual analysis of these catecheses led to the selection of several aspects of this teaching, elements linked by Cyril to biblical documentation of the issues conveyed. Noteworthy are fragments related to the names of the Holy Spirit, the essence of Trinitarian relationships, and the nature of His salvific tasks. Individual issues, as shown by the analysis, elucidate Cyril as a conscientious theologian and catechist of the second half of the fourth century. He was thus working before the Council of Constantinople, on which the study of the Holy Spirit as written down in the Credo had just been resolved.
\end{abstract}

Keywords: Cyril of Jerusalem; symbol of faith; Holy Spirit; catechumenical catecheses; biblical message

Cyryl, biskup Jerozolimy w latach 348-387, zapisał się w dziejach refleksji teologicznej jako autor 24 katechez: protokatechezy, 18 wygłoszonych do katechumenów oraz 5 tzw. mistagogicznych, które zostały skierowane do nowo ochrzczonych. Wyróżniał się umysłem umiarkowanym i zrównoważonym, zabiegając o przywrócenie jedności 
i pokoju pomiędzy zwaśnionymi stronami - arianami i antyarianami ${ }^{1}$. Jego katechezy zawierają wyjaśnienie prawd wiary, które oparł na tzw. symbolu wiary, metodzie powszechnie stosowanej². Kierując się jerozolimskim symbolem, zdołał przedstawić słuchaczom całość wiedzy teologicznej3.

W cyklu katechez wygłoszonych do katechumenów dwie odnoszą się do Ducha Świętego, a są nimi Katecheza XVI i Katecheza XVII. Ich lektura wykazuje, że mówca swój wykład o trzeciej Osobie Boskiej oparł na przekazie biblijnym. Umiejętnie komentując poszczególne teksty biblijne, Cyryl zwraca uwagę na różne aspekty odnoszące się do katechetycznego przekazu wiedzy o Duchu Świętym. Celem niniejszego opracowania jest ukazanie biblijnej metody przekazu nauczania o Duchu Świętym w odniesieniu do Jego nazw, trynitarnych relacji oraz Jego natury i zbawczej roli. Poszczególne odniesienia zostaną przedstawione na podstawie analizy treściowej wymienionych dwóch katechez.

\section{Biblijne założenia nauczania o Duchu Świętym}

Cyryl Jerozolimski z wielką odpowiedzialnością przystępował do wygłaszania nauk katechumenalnych, których treść opierał na przyjętym w Jerozolimie symbolu wiary ${ }^{4}$. Nauczając o wierze „w jednego Ducha Świętego, Pocieszyciela”, rozpoczął katechetyczną refleksję o Nim stwierdzeniem bardzo stanowczym: „Prawdziwie Duchowej potrzebujemy łaski, abyśmy mogli rozprawiać o Duchu Świętym. Nie dlatego, by - co jest niemożliwe - tak mówić, jak tego wymaga ważność sprawy, lecz byśmy czerpiąc z Pisma Świętego nie popadli w niebezpieczeństwo"s. Cyryl w pierwszym zdaniu wypowiedzianym do katechumenów o Duchu Świętym w Katechezie XVI uczynił niezwykle istotne założenie, w którym zapowiedział metodę przekazywania im wiedzy katechetycznej. Polegała ona bowiem na stosowaniu zasady powoływania się na wypowiedzi Pisma Świętego ${ }^{6}$. Przy tej okazji podał powód takiego zabiegu, a jest nim poprawność doktrynalna, pozwalająca uniknąć popadnięcia w niebezpieczeństwo błędnego nauczania o tej Osobie Boskiej.

\footnotetext{
Hamman, Portrety Ojców Kościoła, 158.

Bliższe wyjaśnienie zasad tej metody przekazują: Carpenter, „Creeds and Baptismal Rites”, 1-11; Crehan, Early Christian Baptism and the Creed, 25-40; Maggioni, „I simboli della fede”, 9-13; Pietras, „Geneza Symbolu Apostolskiego", 63-76.

3 Wiele informacji dotyczących katechez Cyryla podają: Kania, „Istotne cechy katechezy”, 75-81; Day, „Lent and the Catechetical Program”, 129-147; Kalleres, „Cultivating True Sight”, 431-459.

4 Zob. Daniélou, La catechesi, 91.

5 Cyrillus Hierosolymitanus, Catechesis XVI, 1 (BOK 14,257).

6 Paczkowski, „Teologia świadectwa i doświadczenia”, 56-57.
} 
Biskup, wypowiadając powyższe słowa, jest świadom istniejących za jego czasów heretyckich nauk, krążących w różnych wspólnotach kościelnych chrześcijaństwa. Dlatego przestrzega słuchaczy przed niektórymi błędnymi tezami, wypowiadając do nich radykalne przestrogi. Zestawione obok siebie tworzą swego rodzaju inwektywę, zważając przy tym na fakt, że nauczaniu heretyków poświęcił stosunkowo dużo miejsca w tej katechezie. Mając na uwadze dobro duchowe słuchaczy, Cyryl powiedział do nich:

Niech zamilkną Marcjoniści! [...]. Nie dzielimy Trójcy Świętej, jak to niektórzy czynią, ani jej nie mieszamy jak Sabeliusz. [...]. Inni znów, tak zwani gnostycy, również bezbożni, inne rzeczy powiedzieli przeciw Duchowi Świętemu, niegodziwi walentynianie jeszcze inne. Bezbożny Manes bezczelnie się głosił za Pocieszyciela, posłanego przez Chrystusa. [...]. Nienawidź tych ludzi i uciekaj przed tymi, co bluźnią Duchowi Świętemu! [...]. Nienawidzić też należy marcjonistów, co z Nowego Testamentu wyrzucili słowa Starego Przymierza. [...]. Nienawidzić też trzeba wspomnianych gnostyków, [...]. Nienawidzić też należy katafrygów i założyciela tego zła Montanusa, z jego dwiema rzekomymi prorokiniami, Maksymillą i Pryscyllą7.

Mocno rozbudowane $\mathrm{w}$ informacje pouczenie dotyczące błędnego nauczania heretyków, wraz z powyższymi ostrzeżeniami, biskup zamieścił w początkowej fazie wygłaszanej katechezy. Już zatem u początku wsłuchiwania się w naukę katechetyczną biskupa o Duchu Świętym kandydaci do chrztu zostali uprzedzeni o istniejących niebezpieczeństwach doktrynalnych i możliwości pobłądzenia $\mathrm{w}$ wierze ${ }^{8}$. Zanim zatem jerozolimski katecheta przystąpił do pozytywnego wykładu nauki o Duchu Świętym, rozpoczął swe nauczanie od wyeliminowania ewentualnie obecnych w umysłach i duszach słuchaczy jakichś heretyckich o Nim opinii. Jak ukazują to przytoczone wypowiedzi, Cyryl niezwykle stanowczo wyraził swą opinię o błędnowiercach, wypowiadając ostre przeciwko nim słowa. Jednocześnie poprzez podanie imion twórców aktualnych wówczas herezji dokonuje swego rodzaju rejestru tych przewodników, których należy się wystrzegać. Zestawienie obok siebie błędnych opinii o Duchu Świętym stanowi tym samym pouczenie w aspekcie negatywnym, to znaczy, jak katechumeni nie powinni Go postrzegać.

Wyżej przedstawione zastrzeżenia względem działalności heretyków Cyryl poprzedził bowiem słowami zapraszającymi słuchaczy do współodpowiedzialności za prawidłowy przekaz doktryny wiary:

Mówiąc o Duchu Świętym, nie zamierzamy dawać dokładnie wyjaśnienia Jego natury - bo jest to niemożliwe; chcemy tylko wymienić dotyczące Go różne błędy, abyśmy kiedyś nie

Cyrillus Hierosolymitanus, Catechesis XVI, 4-10 (BOK 14,258-261).

Elementy polemiki Cyryla z heretykami przedstawił: Widok, „Polemika antyheretycka”, 423-442. 
popadli w nie przez niewiedzę. [...]. Jeśli przytoczymy jedną czy drugą wypowiedź heretycką, uczynimy to dla swego zabezpieczenia, [...]; nie chcemy w tym ponosić winy, tak my, którzy uczymy, jak i wy, którzy słuchacie?

Ważnym elementem tej wypowiedzi jest zastrzeżenie, które mówca postawił względem własnej osoby jako katechety. Zapowiedział bowiem, że nie zamierza „dawać dokładnie wyjaśnienia Jego natury”, dodając, że „jest to niemożliwe”. Wypowiadając to zastrzeżenie, użył kluczowego terminu w ówczesnych dyskusjach tryni-

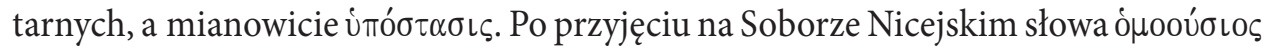
do tekstu wyznania wiary, które wywołało w następnych dekadach sporo dyskusji,

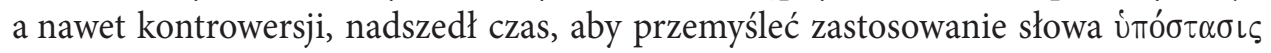
w rozważeniu kwestii trynitarnych. Słowo to nosiło zmienną semantykę ${ }^{10}$, aż dopiero Bazyli Wielki w Liście 38, napisanym w roku 369 lub 370, określił zakres semantycz-

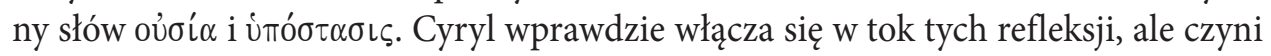

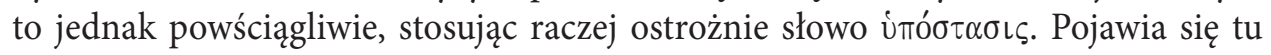
pytanie dotyczące powodu rezygnacji przez niego z podawania owych dokładnych wyjaśnień natury Ducha Świętego ${ }^{11}$ i jednocześnie z zabrania głosu co do interpre-

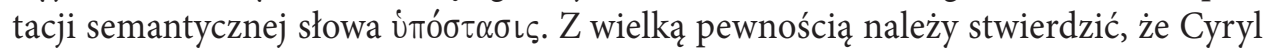
w okresie wygłaszania swoich katechez nie dysponował żadnymi orzeczeniami synodalnymi bądź naukami ówczesnych pasterzy, gwarantującymi prawidłową wykładnię natury Ducha Świętego. Jako biskup Jerozolimy sprawował swój urząd w latach 348-387, będąc troskliwym pasterzem i subtelnym nauczycielem wiary ${ }^{12}$. Natomiast katechezy wygłosił w roku 348 lub 350 w bazylice Grobu Pańskiego ${ }^{13}$, którą wybudował cesarz Konstantyn. Zatem do orzeczenia soborowego w Konstantynopolu z 381 r. pozostało ponad 30 lat. Przed tym rokiem wprawdzie powstały na Wschodzie pisma poświęcone Duchowi Świętemu, jednak ich treść nie była znana Cyrylowi, gdyż zostały napisane po wygłoszeniu jego katechez. Atanazy bowiem jako pierwszy wypowiedział się o Duchu Świętym w Listach do Serapiona, które napisał w roku 359 lub na początku $360^{14}$, a Bazyli Wielki o wiele obszerniejsze i głębsze w swej treści dzieło pt. O Duchu Świętym pozostawił około 375 r. ${ }^{15}$ Obawa Cyryla o ewentualne błędne wyłożenie katechumenom nauki o Duchu Świętym była więc uzasadniona.

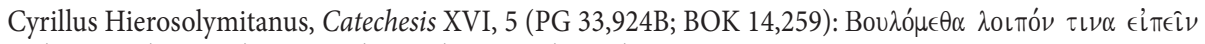

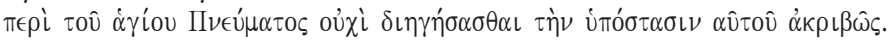

10 Historię stosowania tego terminu i odniesienia semantyczne opisują m.in.: Andresen, „Zur Entstehung und Geschichte”, 1-39; Halleux, „ «Hypostase» et «personne»", 313-369, 625-670.

11 Kontekst tej sytuacji wyjaśnia: Fiedrowicz, Teologia ojców Kościoła, 342.

12 Quasten, Patrologia, 365.

13 Zob. Altaner - Stuiber, Patrologia, 422.

14 Quasten, Patrologia, 60.

15 Quasten, Patrologia, 212. 
Należy mieć ponadto na uwadze fakt, że odbiorcami jego nauk byli katechumeni, a więc osoby w ogóle niebędące wtajemniczone $\mathrm{w}$ wielowątkowe dysputy trynitarne.

Z powyższych względów jerozolimski katecheta powziął decyzję, aby wszelkie idee, które mają składać się na treść dwóch katechez o Duchu Świętym, zostały zaczerpnięte z Pisma Świętego. Głośne wówczas nauki błędnowierców były dla niego przestrogą, aby nie popełnić podobnego odstępstwa. Należy ponadto dostrzec czujność i doktrynalną intuicję Cyryla, że mimo braku odpowiednich orzeczeń, doskonale wskazywał na wadliwe interpretacje odnoszące się do tej Osoby Boskiej. Wynikało to $\mathrm{z}$ tego, że jego poprawna wykładania w tej kwestii była stymulowana wypowiedziami Pisma Świętego. Jego bowiem odpowiedzialność za poprawność głoszonej nauki nie pozwalała mu popełnić przestępstwa doktrynalnego, o czym świadczą słowa: „nie chcemy w tym ponosić winy”. Tę odpowiedzialność odnosi nie tylko do siebie, ale rozszerza ją także na słuchaczy, będących dopiero na drodze do przyjęcia chrztu, dopowiadając: „tak my, którzy uczymy, jak i wy, którzy słuchacie”. W tych słowach wybrzmiewa zarówno pokora pasterza względem katechumenów, jak i pozyskanie zaufania katechumenów do pasterza. Tego typu jego podejście do słuchających posiada ponadto wymiar pedagogiczny, polegający na uzyskaniu optymalnej duchowej i umysłowej łączności pomiędzy obiema stronami.

$\mathrm{Z}$ powodu zatem rozmaitych idei doktrynalnych, których nauczycielami byli różni heretycy, Cyryl jako podstawę swego nauczania przyjmuje Pismo Święte. To, zastosowane od początku, założenie w sposób bardzo jednoznaczny rozwija, wyjaśniając: „Chcemy to tylko o Duchu Świętym mówić, co jest w Piśmie Świętym. Tym, czego tam nie ma, nie będziemy się zajmować. Sam Duch Święty przemówił w Piśmie Świętym. Powiedział tyle, ile chciał i co zdołamy pojąć" ${ }^{16}$. Te stwierdzenia ponownie jasno precyzują metodę wykładu, która będzie polegała na przywoływaniu i interpretowaniu tych biblijnych opisów, w których zaznaczyło się działanie Ducha Świętego. Tym sposobem katecheta sam nie popadnie w kolejną błędną ideę i jednocześnie będzie w stanie przekazać słuchaczom właściwy zakres wiedzy i pobożności w odniesieniu do Niego.

Po ustaleniu ze słuchaczami zasad katechetycznego przekazu Cyryl kilkakrotnie przypominał swoim słuchaczom podczas katechumenalnych nauk o swojej metodzie wykładu, jakby zapraszając ich do wspólnego i odpowiedzialnego podejścia do tej podstawowej prawdy, jaką jest wiara w Ducha Świętego. Rozprawiwszy się z heretykami, następnie w słowach o nieco spokojniejszym tonie zachęcał katechumenów: „Niech wystarczą te słowa o wyrzuconych z Kościoła. Wróćmy teraz do bożego Pisma i napijmy się wody z naszych naczyń i źródeł. Pijmy z wody żywej, wytryskującej na życie wieczne"17. Mówca przywołał tu znany obraz czerpania ze źródła wody, która posiada życiodajne znaczenie. Wskazuje, że tym źródłem jest Pismo Święte, którego

16 Cyrillus Hierosolymitanus, Catechesis XVI, 2 (BOK 14,257).

17 Cyrillus Hierosolymitanus, Catechesis XVI, 11 (BOK 14,261). 
strumienie wód sięgają aż do życia wiecznego, parafrazując przy tym słowa św. Jana (J 4,14). Świętą księgę Cyryl nazwał „nasze naczynia”, przeciwstawiając tej idei wszelkie inne naczynia heretyckie.

W dalszej części Katechezy XVI pojawia się w sposobie przemawiania biskupa forma dyskursu: „Ponieważ o Duchu bez bliższego określenia podało Pismo Boże wiele różnych rzeczy i zachodzi niebezpieczeństwo, aby kto tego nie pomieszał, [...], zachodzi potrzeba ustalenia, co rozumie Pismo pod Duchem Świętym"18. Jerozolimski biskup tymi słowami poświadcza, że doskonale znał treść Pisma Świętego i jest gotów wyszczególnić wszystkie te miejsca, w których pojawia się słowo „duch”. Potwierdza to lektura obu katechez, gdzie omawia on poszczególne aspekty duchowych rzeczywistości, a przede wszystkim działanie Ducha Bożego, co szerzej zostanie przedstawione niżej. W tym miejscu warto jedynie zauważyć umiejętność dokonywania przez niego syntetyzujących refleksji opartych na księgach biblijnych. Przede wszystkim jednak należy dostrzec podejście katechety względem słuchaczy, polegające na informowaniu ich o swoich zamiarach. Jego zapowiedź wyrażona słowami "zachodzi potrzeba ustalenia, co rozumie Pismo" stanowi zachętę, aby słuchający go katechumeni otworzyli się na jego sugestie, akceptując i wspólnie rozważając czynione przez ich katechetę biblijne ustalenia odnoszące się do Ducha Świętego.

Ostatni passus Katechezy XVI także zawiera myśl, którą Cyryl dzieli się z katechumenami odnośnie do dalszych etapów ich kształcenia, konkludując ją takimi słowami: „Można by przytoczyć jeszcze wiele świadectw ze Starego Testamentu, aby lepiej przedstawić naukę o Duchu Świętym. Lecz czas jest krótki i trzeba zachować miarę w słuchaniu. Dlatego zadowólmy się tym, cośmy dotąd podali ze Starego Zakonu i przejdźmy w najbliższej katechezie do tego, co jest w Nowym" ${ }^{19}$. W tej wypowiedzi ujawnia się doświadczenie katechetyczne biskupa odnoszące się zarówno do umiejętnego doboru treści co do ilości przekazywanych informacji („trzeba zachować miarę w słuchaniu”), jak i co do źródeł ich pochodzenia („zadowólmy się tym, cośmy dotąd podali ze Starego Zakonu i przejdźmy w najbliższej katechezie do tego, co jest w Nowym"). Odpowiednie rozdzielenie wiadomości biblijnych, pochodzących z obu Testamentów, stanowi również element przyjętej przez Cyryla metody podawczej.

Rozpoczynając Katechezę XVII, jerozolimski biskup znowu dokonuje metodologicznych zabiegów poprzez oznajmienie słuchaczom swoich zamiarów dydaktycznych wobec nich: „Obecnie, jeśli Bóg pozwoli, zajmiemy się - ile to możliwe - świadectwami z Nowego Testamentu. Tam - by zachować miarę w nauce - miarkowaliśmy nasz zapał, bo nie do wyczerpania jest nauka o Duchu Ŝ́więtym, teraz też małą część przytoczymy tego, co zostało do powiedzenia"20. Tej wstępnej zapowiedzi towarzyszy świadomość katechety, że nauka o Duchu Świętym jest „nie do wyczerpa-

\footnotetext{
Cyrillus Hierosolymitanus, Catechesis XVI, 13 (BOK 14,262).

Cyrillus Hierosolymitanus, Catechesis XVI, 32 (BOK 14,272).

Cyrillus Hierosolymitanus, Catechesis XVII, 1 (BOK 14,277).
} 
nia”, jednak pragnie on „zachować miarę" w powoływaniu się na świadectwa Starego i Nowego Testamentu. Tego typu podejście zawiera sprawdzoną pedagogiczną zasadę, by poprzez niedosyt, a nie przesyt, przekazywać wychowankom wiedzę $\mathrm{w}$ danym zakresie. Do takiej postawy przyznaje się Cyryl, kiedy oświadczył: „miarkowaliśmy nasz zapał”. Zatem swoją pasterską posługę, odznaczającą się zapałem w nauczaniu prawd Ewangelii, sam od siebie musiał nieco ograniczyć. Nie może taka postawa uchodzić za naganną, ponieważ nauczał dopiero katechumenów, a więc początkujących w poznawaniu zasad wiary chrześcijańskiej. Ograniczenie ilości informacji, niedosyt w przekazie, trzymanie się odpowiedniej miary - są oznakami pedagogicznego wyczucia biskupa.

Cyryl jako doświadczony katecheta przerywa w połowie swej mowy nauczanie i na zasadzie dygresji mówi uczestnikom katechezy o bieżących trudnościach w przekazie omawianej problematyki, podając jednocześnie dalszy zarys tematyczny. Tę kwestię zapowiada w następujący sposób:

Wiele dziś mówiliśmy i słuchanie już was pewnie zmęczyło. Lecz jeszcze wiele pozostało. Przydałaby się trzecia nauka o Duchu Świętym, a nawet więcej. Jedno i drugie trzeba nam wybaczyć. [...], jednak nie zdołamy przytoczyć wszystkich świadectw z Nowego Testamentu. Nie wymieniliśmy świadectw z Dziejów Apostolskich, [...], nie przytoczyliśmy świadectwa z listów katolickich i z czternastu listów Pawła. Z tych to pism spróbujmy teraz jak $\mathrm{z}$ wielkiej ląki zerwać choćby parę kwiatów ${ }^{21}$.

To celowo przytoczone dłuższe wyjaśnienie metodologiczne Cyryla powinno wprowadzić każdego odbiorcę tych słów w atmosferę relacji na linii mistrz - uczeń. Mistrz, jakim jest jerozolimski biskup, rozumie zmęczenie uczniów spowodowane przyjmowaniem mnóstwa informacji - w tym przypadku biblijnych faktów ukazujących działanie Ducha Świętego w dziejach zbawienia. Ponadto uświadamia słuchających o możliwości przekazania im jeszcze większej ilości wiedzy, ale czego nie czyni z powodu różnych ograniczeń. Następnie zapowiada, co wypada jeszcze poznać, by ukazała się względnie pełna nauka o Duchu Świętym. Mówca, takim sposobem zwrócenia się do katechumenów, pozyskał ich serca, a umysły nakłonił do dalszego wytężonego słuchania.

Po kolejnym etapie katechumenalnej nauki o Duchu Świętym biskup ponownie zatrzymuje tok swej narracji i zwraca się do słuchaczy z niezwykle pokornymi słowami:

Doszedłszy w swej mowie dotąd, proszę was, ukochani, a raczej mieszkającego w Pawle Ducha, o wybaczenie, iż wskutek swej słabości i waszego zmęczenia nie zdołam przed-

21 Cyrillus Hierosolymitanus, Catechesis XVII, 20 (BOK 14,286). 


\section{NORBERT WIDOK}

stawić wszystkiego. Kiedyż bowiem opowiem godnie przedziwne czyny Pawła, które on zdziałał w mocy Ducha Świętego i w imię Chrystusa?22.

Katecheta wypowiada uwagę nakierowaną do siebie samego oraz do słuchaczy. U siebie dostrzega słabość, zapewne fizyczną, że nie podoła dalszemu wysiłkowi w przedstawianiu potęgi Ducha Świętego w czynach św. Pawła, natomiast w grupie katechumenów zauważa zmęczenie. W tej sytuacji mówca prosi o wybaczenie, czyli o zrozumienie zaistniałych okoliczności z powodu fizycznych wydolności ludzkiej natury. Akcentując biblijne ujęcie nauczania prawd wiary oraz wykorzystanie ówczesnych pedagogicznych sposobów przekazu, należy dodać, że Cyryl czerpie wiele z tradycji aleksandryjskiej (także za pośrednictwem pobliskiej Cezarei), zwłaszcza ze spuścizny Klemensa Aleksandryjskiego i Orygenesa, dzięki którym wprowadził w swe nauczanie elementy alegoryzmu ${ }^{23}$.

Tymczasem zapał biskupa i odpowiedzialność za przekaz Bożej nauki podpowiada mu, by kontynuować mowę w takim samym stylu. Dlatego następne passusy katechezy są jedynie streszczeniem niektórych wątków z działalności św. Pawła ${ }^{24}$. Mówca zdaje sobie sprawę, że bogactwo treści do przekazania jest obfite, ale możliwości percepcyjne słuchaczy nieco ograniczone. Dlatego biskup, zanim wypowie zachętę do radosnego przeżycia przez nich sakramentu chrztu i udzieli końcowego błogosławieństwa, delikatnie prosi o spełnienie jednego zadania. Jest ono ujęte w kontekst swego rodzaju życzenia do nich skierowanego, ujętego następnie w formułę trynitarną. Treść tej pasterskiej zachęty jest następująca:

Niech łaska Ducha Świętego wybaczy nam pominięcie czegoś z braku czasu! Wam zaś, słuchacze, niech wleje wiedzę tego, cośmy opuścili! Gorliwi niech to sobie uzupełnią częstym czytaniem boskiego Pisma! Ale już na podstawie tych Katechez i mych wcześniejszych nauk niech umocnią swą wiarę w jednego Boga Ojca wszechmogącego i w Pana naszego Jezusa Chrystusa jednorodzonego Syna i Ducha Świętego Pocieszyciela ${ }^{25}$.

Należy stwierdzić, że słowa powyższej zachęty zawierają wiele troski biskupa wobec swoich podopiecznych, a także stanowią formę zamknięcia nauki o Duchu Świętym przekazywanej w obydwóch katechezach. Jednocześnie są też życzliwą informacją o zakończeniu wzajemnej komunikacji pomiędzy katechetą a słuchaczami, polegającej na okazywaniu im zaufania przez mówcę, wyjaśnianiu istoty zastosowanej metody, a nawet określaniu trudności wynikających z braku czasu, nadmiernej ilości wiedzy do przekazania czy też zwykłego zmęczenia. Na podstawie dokonanych

22 Cyrillus Hierosolymitanus, Catechesis XVII, 30 (BOK 14,290).

23 Głębokiej analizy tej problematyki dokonał: Stephenson, „Cyril of Jerusalem and the Alexandrian Heritage", 573-593.

24 Zob. Cyrillus Hierosolymitanus, Catechesis XVII, 30-33 (BOK 14,290-292).

25 Cyrillus Hierosolymitanus, Catechesis XVII, 34 (BOK 14,292-293). 
analiz tekstowych Cyryl jawi się jako doskonały dydaktyk, w sposób odpowiedni i trafny stosujący wybraną przez siebie metodę.

\section{Biblijne nazwy Ducha Świętego}

Cyryl w przekazie nauki o Duchu Świętym jest wierny przyjętym przez siebie zasadom, to znaczy, aby opierać się na teksach Pisma Świętego. Z tego względu wykorzystuje te nazwy odnoszące się Ducha Świętego, które występują w świętych księgach. Na początku Katechezy XVI jednoznacznie oznajmia katechumenom, że ,jeden jest Duch Święty Pocieszyciel"26. To stwierdzenie jest dosłownym powtórzeniem prawdy wiary zapisanej w cytowanych już wyżej słowach symbolu jerozolimskiego. Katecheta za punkt wyjścia obrał zatem przyjęty w lokalnej pobożności tytuł Ducha Świętego (㐱 z Ewangelii św. Jana, który jako jedyny spośród Ewangelistów posługuje się tym terminem (J 14-16). Tłumacz polskiego przekładu katechezy Cyryla zastosował pojęcie „Pocieszyciel”, stosowane w polskich przekładach biblijnych od XVI wieku i mające jeden odcień znaczeniowy pośród innych ${ }^{27}$. Tymczasem to pojęcie w różnych kontekstach przekazu Ewangelii św. Jana zawiera takie znaczenia, jak: „orędownik”, „adwokat”, „obrońca”, „wspomożyciel”, a także „pocieszyciel”28. Cyryl, posługując się terminem greckim П $\alpha \alpha_{\alpha} \alpha \lambda \eta \tau \varsigma$, , miał na uwadze wszystkie podane odniesienia, na co będą wskazywały interpretacje jego wypowiedzi w dalszych etapach niniejszego przedłożenia.

Godnym zastanowienia jest użycie przez Cyryla słowa ,jeden” (" $(\epsilon)$ w odniesieniu do Ducha Świętego. Raczej należy zakładać, że tego typu określenie zastosował on na zasadzie analogii do orzekania w ten sam sposób o pozostałych Osobach Boskich, co

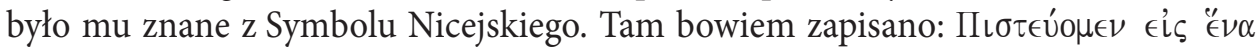

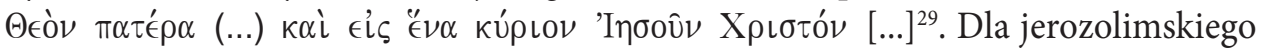
katechety było czymś oczywistym, że należało wyznać wiarę także w jednego Ducha Świętego. Tak, według niego, brzmiący zapis nie pojawił się jednak w Symbolu Kon-

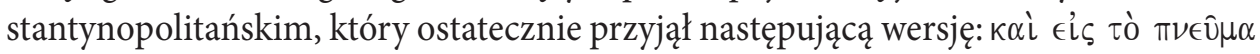

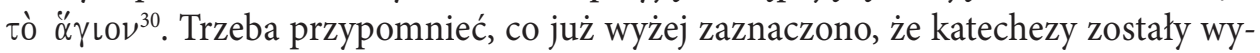
głoszone w roku 348 lub 350, po czym w latach 357-360 pojawili się błędnowier-

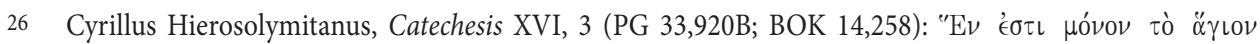

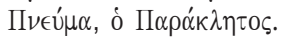

27 Jankowski, Zarys pneumatologii, 38.

28 Szersze mówienia semantyki biblijnej tych określeń przedstawili m.in.: Gryglewicz, Jezusowe przemówienia, 136-148; Congar, Wierzę w Ducha Świętego, 91-102.

29 „Wyznanie wiary 318 Ojców”, 24.

30 „Wyznanie wiary 150 Ojców”, 68.
} 
cy: Aecjusz i Eunomiusz, egipscy „tropicy” oraz Macedoniusz i jego zwolennicy ${ }^{31}$, a dopiero potem ortodoksyjni przedstawiciele nauki o Duchu Świętym, jak: Atanazy, Bazyli, Grzegorz z Nazjanzu i Grzegorz z Nyssy ${ }^{32}$. W celu podkreślenia natomiast

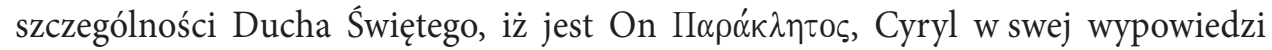

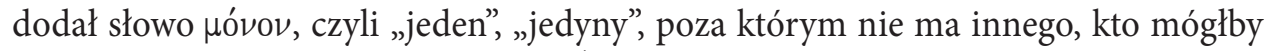
posiadać takie same cechy jak Duch Święty. W dalszej części tej katechezy próbuje wyjaśnić, co ten tytuł oznacza, mówiąc: „Duch Święty zwie się Pocieszycielem, bo pociesza, wlewa otuchę, usuwa słabość”33. Wymienione czynności mają charakter wzmacniający duchową sferę człowieka. Dzięki nim natura ludzka jest chroniona przed złym działaniem. Do tego tytułu katecheta kilkakrotnie nawiązał w swym nauczaniu, podając przy tym lapidarne wyjaśnienia.

Nawiązując do stwierdzenia św. Jana, biskup skierował do słuchaczy następujące słowa: „Ten dobry, uświęcający, pomagający Nauczyciel Kościoła, Duch Święty, Pocieszyciel, o którym mówił Zbawiciel: «On was wszystkiego nauczy i przypomni wam

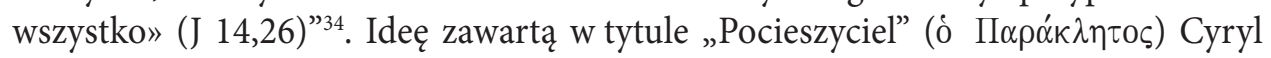
łączy z funkcją nauczania, opierając swą wypowiedź na słowach Jezusa Chrystusa zapisanych w Ewangelii św. Jana. Dla biskupa momentem decydującym jest autorytet Syna Bożego, który wskazuje na nauczającą rolę Ducha Świętego. W ocenie katechety Jego funkcja nauczająca wynika bezpośrednio z tytułu „Pocieszyciel”, gdyż według niego rolę pocieszającą spełnia ten, kto wszystkiego uczy i przypomina. W tym kontekście pojawia się kolejny tytuł Ducha Świętego - Nauczyciel Kościoła (oîtos

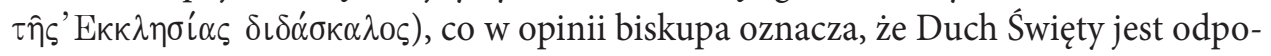
wiedzialnym za szerzenie nauczania prawd wiary i moralności wewnątrz wspólnot kościelnych. Ten tytuł w wypowiedzi Cyryla pełni funkcję uzupełniającą i wzmac-

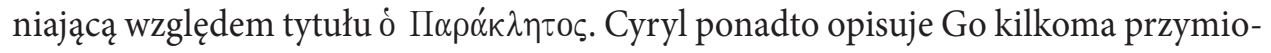

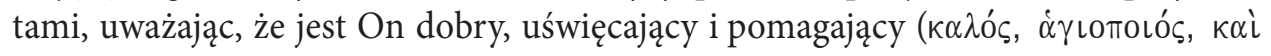
ßoךӨós). Niewątpliwie są to określenia podkreślające walory dydaktyczne nauczyciela w ogóle i dlatego też znalazły odniesienie do Ducha Świętego.

W dalszej części Katechezy XVI biskup ponownie użył powyższego tytułu,

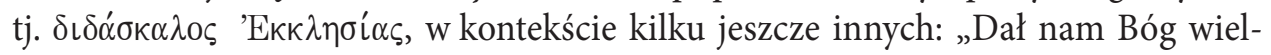
kiego pomocnika i obrońcę, wielkiego nauczyciela Kościoła, wielkiego strażnika”35. Te słowa biskup wypowiedział w kontekście działalności innego ducha, którym jest szatan. Z tego też powodu nazwał Ducha Świętego kolejnymi, obok „wielki nauczy-

31 Zob. Sesboüé - Wolinski, Bóg zbawienia, 234-236.

32 Kelly, Początki doktryny chrześcijańskiej, 194-199.

33 Cyrillus Hierosolymitanus, Catechesis XVI, 20 (BOK 14,267).

34 Cyrillus Hierosolymitanus, Catechesis XVI, 14 (PG 33,937B; BOK 14,263): 'O yò

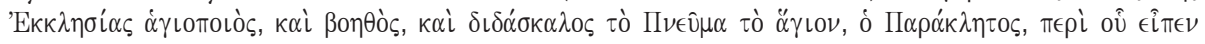
ò $\Sigma \omega \tau \eta \dot{\rho} \rho$.

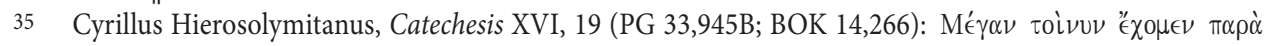

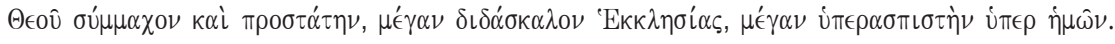




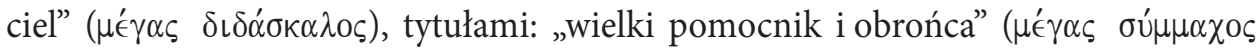

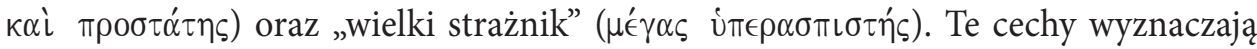
Mu kolejną rolę względem Kościoła, aby go bronił i strzegł przed aktywnością szatana. Należy także zauważyć, że Cyryl poszczególne funkcje Ducha Świętego określa przymiotnikiem „wielki” ( $\mu$ '́ $\gamma \alpha \varsigma)$, co jeszcze bardziej potęguje Jego moc i działanie.

Po niedługiej chwili katechumeni usłyszeli podobne stwierdzenie na temat Ducha Świętego, tym razem wypowiedziane w kontekście tronów anielskich: „Nad nimi wszystkimi dany jest przez Boga Ten, który uczy i uświęca - Pocieszyciel”36. Tytuł odnoszący się do Ducha Świętego - „Pocieszyciel” - został w tej wypowiedzi zastosowany jako pojęcie nadrzędne o randze terminus technicus. Biskup powtarza wcześniej wyszczególnione czynności bądź cechy Ducha Świętego, który jest nauczy-

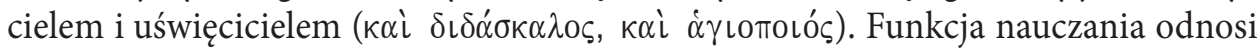
się do sfery umysłowej, natomiast uświęcanie dotyczy duchowej przestrzeni człowieka. Przy końcu Katechezy XVI znajduje się ponowne podkreślenie jednej z tych czynności: „Pocieszyciel Duch Święty, który uświęca każdą rozumem obdarzoną istotę ${ }^{37}$, gdzie ponadto tytuł „Pocieszyciel” występuje jako nazwa nadrzędna.

Cyryl, rozpoczynając Katechezę XVII, uczynił w odniesieniu do tytułów Ducha Świętego istotne metodologiczne pouczenie, mówiąc:

Aby nikt w swej niewiedzy z różnych nazw Ducha Świętego nie wyciągnął wniosków, iż są różne Duchy, a nie jeden jedyny, w swej trosce o ciebie podał Kościół katolicki w wyznaniu wiary, byś wierzył „w jednego Ducha Świętego, Pocieszyciela, [...]”. Masz więc wiedzieć, że są różne nazwy, ale jeden jest Duch Święty ${ }^{38}$.

Te wyjaśnienia, odnoszące się do treści przekazywanej przez biskupa wiedzy katechumenalnej, stanowią ważne i odpowiedzialne podejście dydaktyczne względem słuchaczy. W połowie bowiem nauki o Duchu Świętym tego rodzaju ustawienie doktrynalne okazuje się potrzebne. Biskup przypomina bowiem stwierdzenie z poprzedniej katechezy, oznajmujące, że Duch Święty jest „jeden” ('ڤ ( $\mu$ óvov), mimo że odnoszą się do Niego różne nazwy. Istotą zatem tego wyjaśnienia jest $\mathrm{z}$ jednej strony wskazanie na różnorodność nazw określających Ducha Świętego, co do których biskup już wcześniej dokonał wieloaspektowego pouczenia. Z drugiej strony w powyższej wypowiedzi obecne jest ponadto ważne stwierdzenie, zawiera-

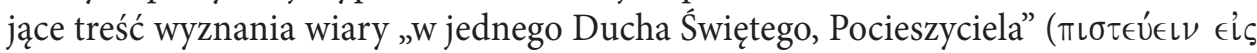

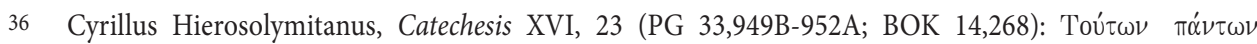

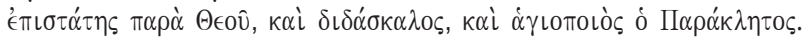

37 Cyrillus Hierosolymitanus, Catechesis XVI, 31 (BOK 14,272).

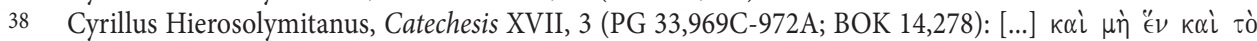

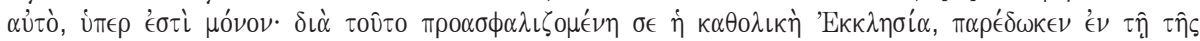

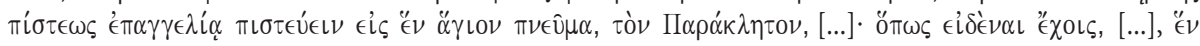

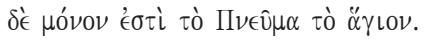




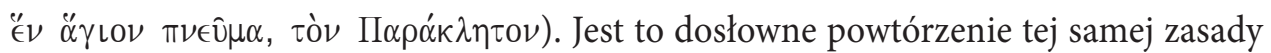
wiary, którą Cyryl wypowiedział na początku Katechezy XVI, a o której wyżej więcej powiedziano. Natomiast obecnie, w Katechezie XVII, wypowiadając tę właśnie praw-

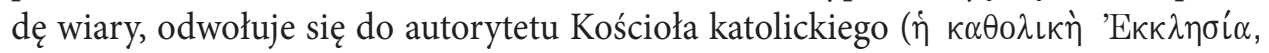

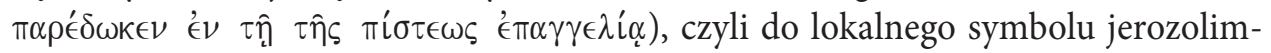
skiego.

Dlatego w drugiej katechezie poświęconej Duchowi Świętemu biskup z jeszcze większą atencją wymienia szereg nazw określających tę Osobę Boską. W kolejnym passusie swej katechezy Cyryl dokonał zestawienia kilku nazw wyjętych z Pisma

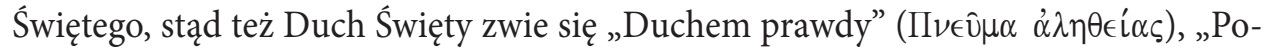

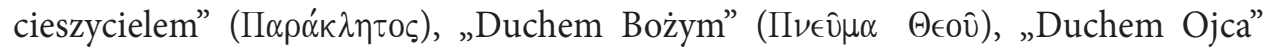

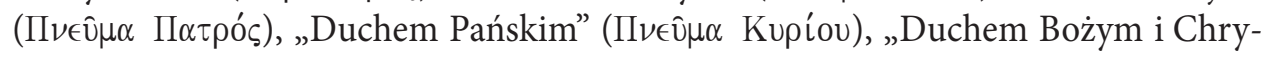

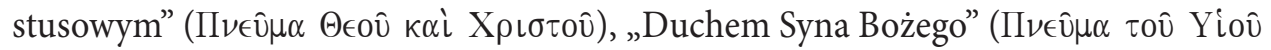

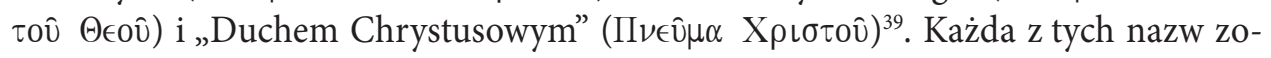
stała udokumentowana przez biskupa cytatem biblijnym w celu uwiarygodnienia przed katechumenami prawdziwości podawanych im tytułów Ducha Świętego. Jak można zauważyć, wyszczególnione nazwy w nieznacznym jedynie stopniu wyrażają relacje wewnątrztrynitarne, a właściwie relację Ducha Świętego względem Ojca i Syna. W nauczaniu Cyryla o Duchu Świętym właściwie nie ma pogłębionej refleksji w sensie ściśle trynitarnym, nacisk został położony raczej na jedność działania Ducha Świętego w historii zbawienia ${ }^{40}$.

Oparcie treści tej katechezy głównie na Nowym Testamencie dało biskupowi możliwość korzystania z szerszego wachlarza odniesień biblijnych, ponieważ księgi Nowego Przymierza zawierają wiele opisów poświęconych Duchowi Świętemu. Dlatego już w następnym passusie Cyryl znowu zwraca uwagę słuchaczy na kolejne zestawienie biblijnych tytułów, nazywając Go „Duchem uświęcenia”

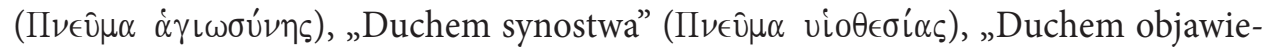

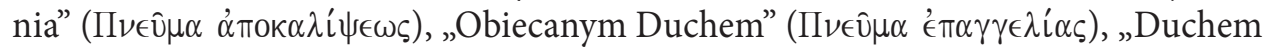

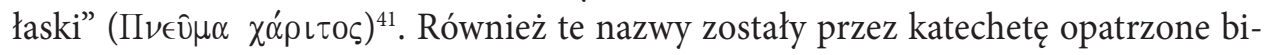
blijnymi cytatami, aby słuchający mogli oprzeć zdobywaną wiedzą na autorytecie Pisma Świętego. Podany zestaw nazw skupia natomiast uwagę na ekonomii zbawczej. Pod tymi różnymi nazwami występuje odczucie obecności Ducha Świętego, które w rzeczywistości jest zawsze to samo ${ }^{42}$. Cyryl w ten sposób przekazuje katechumenom podstawowe pojęcia, które stanowią wyjaśnienie wydarzeń zbawczych, jakie mają miejsce w Kościele Chrystusa.

Zob. Cyrillus Hierosolymitanus, Catechesis XVII, 4 (PG 33,972ABC; BOK 14,278-279).

Daniélou, La catechesi, 104.

Zob. Cyrillus Hierosolymitanus, Catechesis XVII, 5 (PG 33,974AB; BOK 14,279).

Guillet, „Duch Boży”, 233. 
Jedno z tych zbawczych wydarzeń zostało przez katechetę szczegółowiej opisane. Jego relacja przedstawia się następująco:

Jezus wstąpił do nieba i spełnił swą obietnicę. Powiedział do Apostołów: „Będę prosił Ojca i da wam innego Pocieszyciela”. Oni pozostali i czekali na przyjście Ducha Świętego. [...]. W dniu Zielonych Świąt siedzieli, gdy z nieba zstąił Pocieszyciel, Stróż, Uświęciciel Kościoła. On kieruje duszami, prowadzi dręczonych przez burze, daje światło błądzącym, sądzi w walce, wieńczy w zwycięstwach ${ }^{43}$.

Przy opisie tej zasadniczej prawdy zbawczej Cyryl przytoczył wypowiedź św. Jana

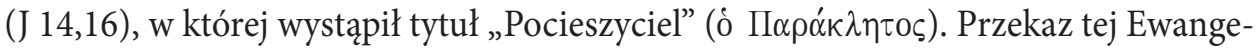
lii, mówiący o przyjściu Ducha Świętego, jest odbiciem idei teocentrycznych i chrystologicznych Kościoła pierwotnego ${ }^{44}$. Dla katechety jest to podstawowy tytuł, który przewija się przez obydwie katechezy i który stanowi dla niego pojęcie wyjściowe do dalszych refleksji doktrynalnych. W powyższym pouczeniu rozwinięciem tego tytułu są kolejne, stanowiące swego rodzaju dopełnienie semantyczne tego wiodącego,

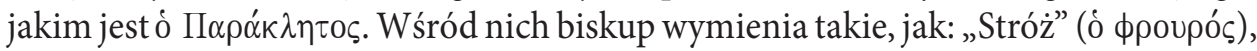

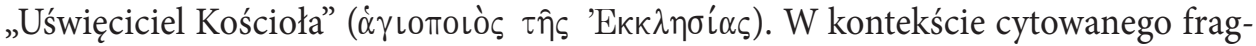
mentu biskup wprawdzie bliżej nie wyjaśnia tych nazw Ducha Świętego, jednak ich semantyczny nośnik jest wyrazisty. Duch Święty bowiem mocą swoją strzeże wspólnotę Kościoła, a słanymi łaskami nieustannie dokonuje dzieła Jego uświęcania. Dlatego biskup podał następnie kilka czynności uświęcających, adresowanych wprost do ludzi jako członków Kościoła, wobec których Duch Święty „kieruje duszami”, „prowadzi dręczonych”, „daje światło”, „sądzi w walce” i „wieńczy w zwycięstwach”. Cyryl przyznał Duchowi Świętemu tak wzniośle brzmiące tytuły ze względu na zadania pełnione przez Niego w Kościele.

Wielokrotnie powtarzanym w katechezach przez Cyryla tytułem Ducha Świętego jest „Pocieszyciel”, będący pojęciem przejętym z pism biblijnych. Natomiast inne tytuły lub nazwy tej Osoby Boskiej zostały utworzone przez katechetę jako rzeczownikowe formy pochodzące od wielu zbawczych czynności i zadań Ducha Świętego pełnionych w dziejach, a dostępnych poprzez lekturę Pisma Świętego. Tego typu sposób tworzenia nowych nazw dla Ducha Świętego, na podstawie biblijnego przekazu, okazał się bezpiecznym modelem nauczania, pozwalającym uniknąć ewentualnych błędów doktrynalnych.

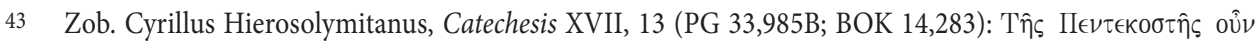

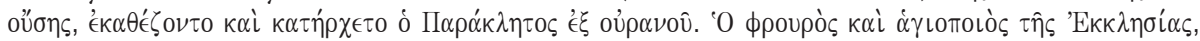

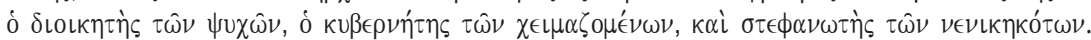

44 Gryglewicz, „Jan Ewangelista o Duchu Świętym w Kościele”, 90. 


\section{Biblijny trynitaryzm}

Jerozolimski biskup w swoim nauczaniu bardzo mocno podkreślał jedyność Osób w Trójcy Świętej. Na początku Katechezy XVI wypowiedział o Niej jednoznaczne stwierdzenie, będące punktem wyjścia do dalszych objaśnień: „Jak Bóg Ojciec jest jeden i nie ma drugiego Ojca, i jak jest jeden jednorodzony Syn i jedno Słowo Boże i nie ma brata, tak też jeden jest Duch Święty i nie ma drugiego równego mu w godności Ducha”" ${ }^{45}$ Na zasadzie analogii do pozostałych Osób w Trójcy Świętej, czyli Ojca i Syna, Cyryl udowadnia podstawową prawdę o Duchu Świętym, mianowicie odnoszącą się do Jego jedyności. Dowodzenie biskupa posiada następujący przebieg:

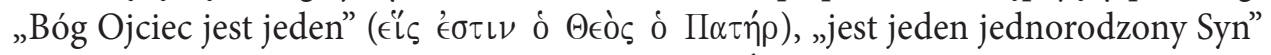

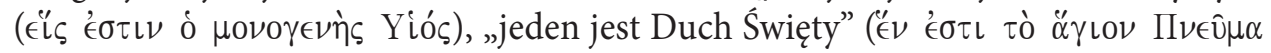

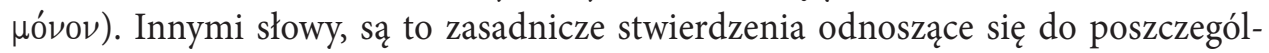
nych Osób w Trójcy wyjęte z jerozolimskiego symbolu wiary. Cyryl jedyność Ducha Świętego zaznaczył w podwójny sposób, tj. poprzez użycie słów ěv i $\mu$ óvov́ dodając, że nie ma On „drugiego równego mu w godności”.

Jedyność, na którą tak bardzo kładzie nacisk mówca, została przez niego wykazana poprzez odniesienie do dziejów zbawienia, co wyjaśnia w ten sposób: „Jeden jest Bóg Ojciec, Pan Starego i Nowego Przymierza, jeden jest Pan Jezus Chrystus, przepowiedziany w Starym i objawiony w Przymierzu Nowym, jeden jest Duch Święty, który zapowiedział przez Proroków Mesjasza i zstąpił po przyjściu Chrystusa, by dać o Nim świadectwo" ${ }^{\prime 6}$. Autor tych słów wyjaśnia słuchaczom udział Osób Trójcy w dziele zbawienia, która w swym teologicznym przesłaniu scala Stary i Nowy Testament. Każda bowiem z Osób Boskich ujawniona została i opisana na kartach Pisma Świętego, dzięki czemu Cyryl udowodnił jedność tych Osób, ciągłość Ich zbawczego działania i jedyność w specyfice Ich udziału w planie zbawienia ${ }^{47}$. Ponadto mówca w swej wypowiedzi nieco bardziej zaakcentował rolę Ducha Świętego względem Jezusa Chrystusa: najpierw bowiem Duch Święty zapowiedział Go jako Mesjasza, a potem dał o Nim świadectwo. Po raz kolejny zatem katecheta w swej

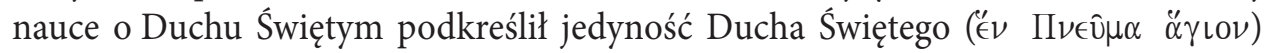

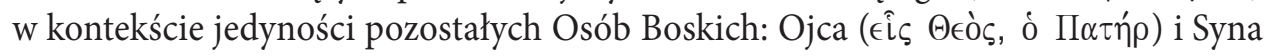

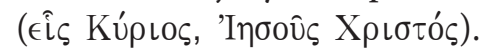

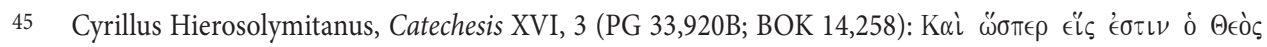

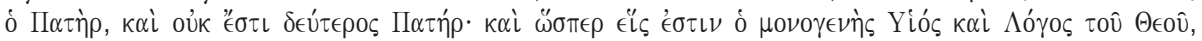

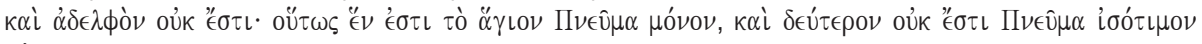

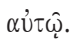

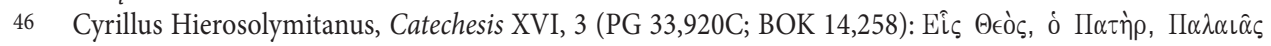

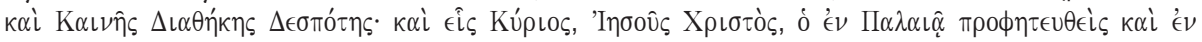

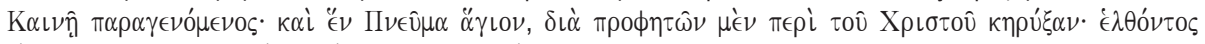

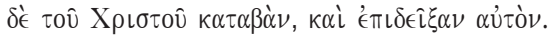


Konsekwencją tak pojętego przez katechetę trynitaryzmu są jego kolejne stwierdzenia o randze dogmatycznej. Biskup bowiem dalej tak naucza:

Niech nikt nie oddziela starego Zakonu od Nowego! Niech nikt nie mówi, że tam jest inny Duch Święty niż tutaj! W przeciwnym razie grzeszy taki przeciw Duchowi Świętemu, który z Ojcem i Synem odbiera uwielbienie i w chwili chrztu w Trójcy Świętej jest wzięty. [...]. Nadzieja nasza jest w Ojcu i Synu i Duchu Świętym ${ }^{48}$.

W pierwszej fazie tej wypowiedzi katecheta streszcza wcześniej wypowiedzianą myśl, podkreślającą istnienie jednego Ducha Świętego w Starym i Nowym Zakonie, co czyni na zasadzie zakazu dzielenia Jego działania i Jego Osoby na dwa etapy dziejów zbawienia. Ostrzega przy tym przed popadnięciem w grzech przeciw Duchowi Świętemu tych spośród swoich słuchaczy, którzy by inaczej uważali. Tę osobową jedyność Ducha Świętego Cyryl motywuje przywołaniem pozostałych Osób, tj. Ojca i Syna, którzy wspólnie odbierają uwielbienie. Jerozolimski biskup stopniowo przechodzi zatem od jedyności Ducha Świętego w Starym i Nowym Przymierzu do jedności Osób w Trójcy Świętej. Ta prawda jest niezwykle istotna przy formułowaniu kolejnej informacji katechetycznej, dotyczącej relacji trynitarnych. W tym punkcie biskup nie podaje jakichkolwiek spekulatywnych informacji o naturze Ducha Świętego, ale jedynie opisuje Go w ścisłym związku z Ojcem i Synem. Skupia bowiem uwagę na relacji, jaką powinni przyjąć wierzący względem Ducha Świętego, a ściślej mówiąc wobec Trójcy Świętej. Wymienia dwie ich postawy: uwielbienie, które należy w takim samym stopniu kierować do każdej Osoby Boskiej, a zwłaszcza podczas chrztu

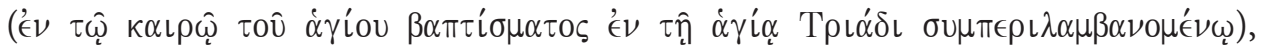

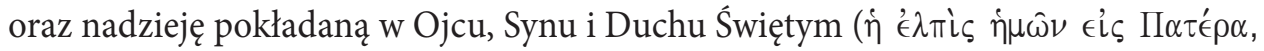

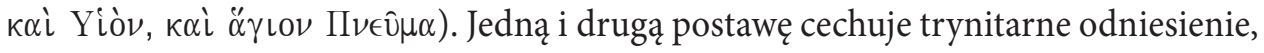
polegające na dostrzeżeniu przez wierzących wszystkich trzech Osób Boskich jako równych i ważnych w ekonomii zbawienia. Katecheta zatem przenosi ciężar swego dyskursu z ściśle teologicznych rozważań na elementy duchowości chrześcijańskiej, którą mają być przeniknięci katechumeni. Uwielbienie Trójcy i nadzieja w Niej pokładana stanowią ważne duchowe wyposażenie dla tych, którzy mają przyjąć chrzest, będący celem każdego katechumena ${ }^{49}$. Cyryl, wspominając ten moment w powyższym pouczeniu, akcentuje szczególny udział Ducha Świętego.

Tak wyraźne podkreślenie przez biskupa trynitarnego aspektu zawiera w sobie ponadto ostrzeżenie przed innowiercami. Stąd kolejne słowa Cyryla wypowiedziane zostały z myślą o nich:

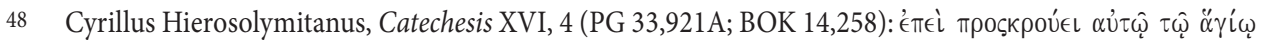

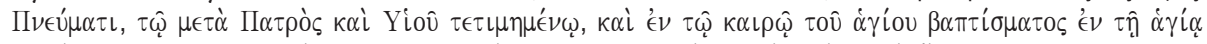

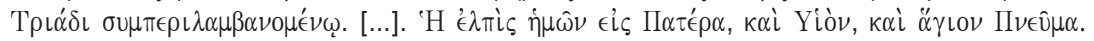




\section{NORBERT WIDOK}

Nie uczymy o trzech Bogach. [...]. Głosimy z Duchem Świętym przez jednego Syna jednego Boga. [...]. Nie dzielimy Trójcy Świętej, jak to niektórzy czynią. [...]. Ze czcią przyjmujemy jednego Ojca, który nam zesłał swego Syna jako Zbawcę. Przyjmujemy jednego Syna, który przyrzekł, iż pośle od Ojca Pocieszyciela. Przyjmujemy Ducha Świętego, który mówił przez Proroków i w dniu Zielonych Świąt zstąpił na Apostołów pod postacią ognistych języków tu w Jerozolimie w kościele apostolskim ${ }^{50}$.

Przytoczony fragment zawiera pouczenie dotyczące troistości istoty Trójcy Świętej. Cyryl najpierw odrzuca ewentualny zarzut koncentrowania uwagi tylko na troistości osób, co staje się oczywistym błędem teologicznym nazywanym tryteizmem ${ }^{51}$, a więc nauczania o trzech Bogach lub podziale Trójcy Świętej. Biskup jest świadomy tego, że pewne odłamy chrześcijan głoszą tego typu błędny pogląd trynitarny. Dlatego z naciskiem wypowiada niezwykle istotne zdanie, ważne dla późniejszych debat trynitarnych: „Głosimy z Duchem Świętym przez jednego Syna jednego Boga” ( $\alpha \lambda \lambda \dot{\alpha}$

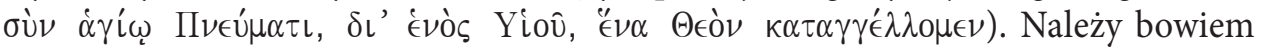
zwrócić uwagę na zastosowane przez biskupa przyimki oúv oraz $\delta\llcorner\alpha$, które potem Bazyli Wielki poddał filologicznej analizie ${ }^{52}$. Po wyrażeniu krytycznego spojrzenia na rozumienie troistości w Trójcy Świętej jerozolimski katecheta przystępuje do ponownego przypomnienia, wcześniej w katechezie wypowiedzianych, prawd odnoszących się do każdej Osoby Trójcy Świętej. Wyliczenie każdej Osoby z osobna wiąże się z podaniem Jej roli w dziejach ekonomii zbawczej w ścisłej łączności z pozostałymi Osobami, dzięki czemu zostaje podkreślona jedność wszystkich Osób Boskich. Ponadto doniosłość swej wypowiedzi Cyryl zaznaczył wskazaniem na miejsce zstąpienia Ducha Świętego pod postacią ognistych języków. Niezwykle przejmujące musiały być słowa katechety, który dopowiedział, że to wydarzyło się „tu w Jerozolimie”. Lokalny kontekst tego zbawczego aktu stanowi o niepowtarzalnym aspekcie wygłaszanej przez biskupa katechezy.

Ważnym stwierdzeniem, odnoszącym się do trynitarnego aspektu nauczania Cyryla, są jego słowa wygłoszone przy końcu Katechezy XVI:

Ojciec daje wszystko przez Syna z Duchem Świętym. Nie są inne łaski Ojca, inne Syna i inne Ducha Świętego; bo jest tylko jedno zbawienie, jedna moc, jedna wiara, jeden Bóg, Ojciec, jeden Pan, Jego jednorodzony Syn, jeden Duch Święty - Pocieszyciel. Niech nam wystarczy to wiedzieć! Natury zaś i istoty Ducha nie należy ciekawie badaćs3.

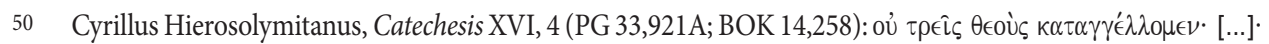

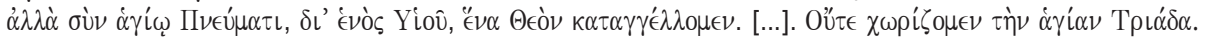

51 Studer, „Triteismo”, 3521.

52 Basilius, De Spiritu Sancto V 7-12 (Brzóstkowska, 89-96; paragraf: Do Ojca również odnosi się zwrot „przez którego", a do Syna "od którego" i tak samo do Ducha).

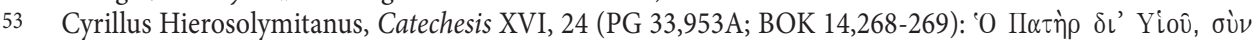

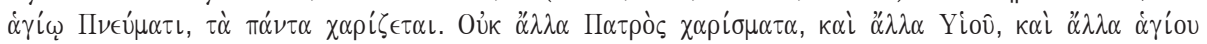


Kontekst teologiczny nauczania o Duchu Świętym w czasach działalności Cyryla przedstawiał się nadzwyczaj skromnie, o czym wcześniej już wzmiankowano. W powyższej wypowiedzi daje się zauważyć ostrożność biskupa w wypowiadaniu zbyt spekulatywnych tez w odniesieniu do istoty Ducha Świętego. Cyryl jest tego w pełni świadomy, gdyż wcześniej wypowiedziane myśli konkluduje jednoznaczną oceną aktualnej sytuacji, aby natura i istota tej Osoby Boskiej nie była zanadto ciekawie badana. Nie wiadomo do końca, co biskup rozumiał w użytym przez siebie zwrocie: „ciekawie badać”. Raczej skupił się na podaniu najważniejszych informacji, które słuchający go katechumeni powinni przyjąć jako podstawową wiedzę teologiczną. W powyższej wypowiedzi ta wiedza dotyczy udzielania pomocy duchowej przez trzy Osoby Boskie względem wierzącego. Polega ona na dawaniu łask, które wedle opinii

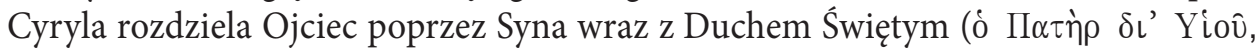

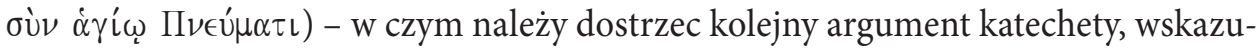
jący na jedność Osób Boskich. Podobnie, jak poprzednio, Cyryl ponownie w swym pouczeniu zastosował te same przyimki, tj. $\delta\llcorner\alpha$ oraz $\sigma u ́ v$. Tę jedność biskup poświadcza ponadto innymi kategoriami charakteryzującymi się jedynością: „jedno zbawie-

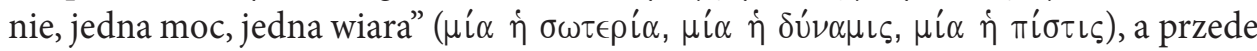

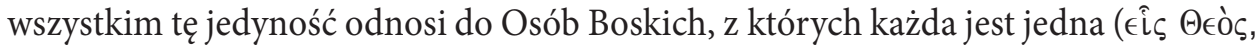

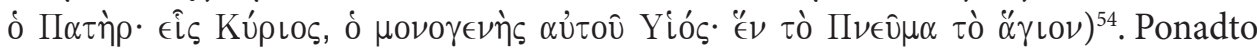
Ducha Świętego opatrzył tytułem przewijającym się przez obydwie katechezy, czyli

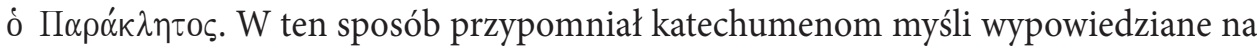
początku katechezy, zamykając jakby klamrą aspekt jedności Osób w Trójcy Świętej.

Na początku Katechezy XVII biskup Jerozolimy, na zasadzie krótkiej syntezy, przypomina słuchającym treści odnoszące się do nauki trynitarnej, które zostały objaśnione w katechezie poprzedniej. Jego słowa brzmią następująco:

Z tego wszystkiego, cośmy powiedzieli przedtem i teraz, wynika, że różne są nazwy, ale jeden i ten sam jest Duch Święty. [...]. Zbawiające, od Ojca, Syna i Ducha Świętego wychodzące działanie na nas jest - jak już powiedzieliśmy - nierozdzielne, wspólne i jedno. Pragnąłbym, abyście pamiętali to, co wam niedawno mówiłem, i dobrze rozumieli, że nie inny w Prawie i u Proroków, a inny w Ewangeliach i u Apostołów, lecz jest jeden i ten sam Duch Święty, który zarówno w Starym, jak i w Nowym Testamencie dyktował Pismo Święte ${ }^{55}$.

Treść przytoczonego fragmentu katechezy jest powtórzeniem wyłożonych wcześniej idei dotyczących Ducha Świętego, wśród których Cyryl, na zasadzie przypomnienia, odniósł się do: kwestii stosowania nazw względem tej Osoby Boskiej, zbaw-

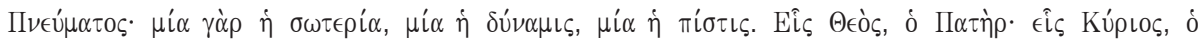

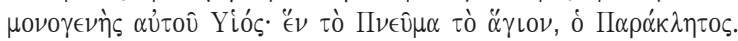

54 Stephenson, „Saint Cyril Trinitarian Theology”, 234-241.

55 Cyrillus Hierosolymitanus, Catechesis XVII, 5 (BOK 14,279). 
czego działania pochodzącego od Trzech Osób i podkreślenia istnienia tego samego Ducha Świętego w Starym i Nowym Testamencie. Tego typu przypomnienie, będące niewątpliwie zabiegiem pedagogicznym, świadczy o doświadczeniu biskupa jako wytrawnego katechety. Powyższe słowa były jednocześnie wstępem do pouczeń i dalszych wyjaśnień, które stały się treścią Katechezy XVII.

Podsumowaniem biblijnego trynitaryzmu mogą być słowa umieszczone w punkcie 11 tej katechezy, w którym jerozolimski biskup zebrał kilkanaście cytatów wypowiedzi Jezusa Chrystusa. Zostały wyjęte z tekstów Ewangelii, głównie św. Jana (J 14-16). Łącznie stanowią swoiste wyłożenie trynitarnego podejścia ze szczególnym zaakcentowaniem obecności Ducha Świętego w Trójcy Świętej i wskazaniem na Jego pochodzenie.

\section{Natura Ducha Świętego i Jego zbawcza rola na kartach Biblii}

Trudnym niewątpliwie zadaniem dla Cyryla było przedstawienie katechumenom natury Ducha Świętego. Sam zaznaczał, jak już zostało wyżej powiedziane, że natury Ducha Świętego nie da się opisać. Mimo takiego zastrzeżenia Cyryl kilkakrotnie odważył się wypowiedzieć w tej kwestii. Z pomocą przyszły mu teksty biblijne, które znał doskonale, jak to wykazuje jego przekaz w tym względzie. Zanim do tego przystąpił, w pierwszych passusach Katechezy XVI odrzucił najpierw wszystkie błędne wyobrażenia o Duchu Świętym, potępiając nauczanie heretyków, o czym już także wyżej wspomniano.

Następnie, z pewnością nieśmiało, jerozolimski mówca przystąpił do pozytywnego wykładu na temat natury Ducha Świętego. Często łączył opis Jego natury z przedstawieniem zadań zbawczych dokonanych w czasach Starego i Nowego Przymierza. W takim właśnie kontekście zauważa, że „Duch Święty ma najwyższą siłę, jest czymś boskim i niezgłębionym. Żyje, posiada rozum, uświęca wszystko, co Bóg stworzył przez Chrystusa, oświeca dusze sprawiedliwych"56. To stwierdzenie dotyczące Jego natury Cyryl wypowiedział na początku katechezy, umieszczając te słowa po kilku zdaniach o charakterze wprowadzającym. Katecheta zatem na początku nauczania o Duchu Świętym zwraca uwagę na przymioty uwzględniające Jego najwyższą siłę

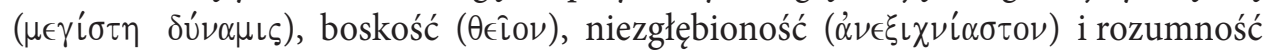

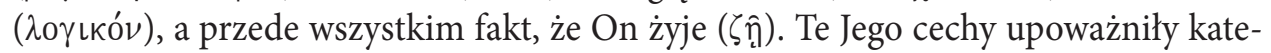
chetę do wyszczególnienia czynności, które z tych cech wynikają: uświęcanie wszyst-

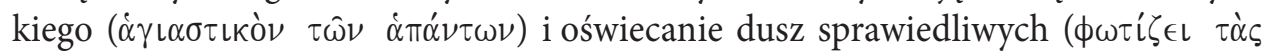

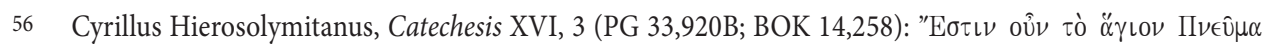

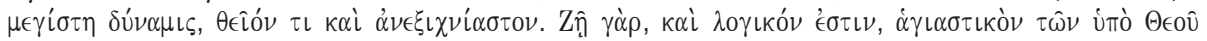

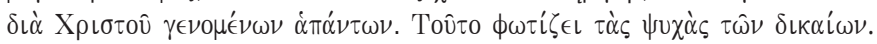




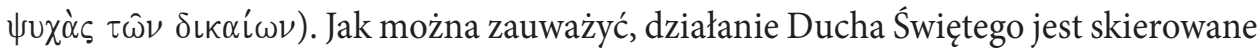
na rzeczywistość stworzoną oraz na byty rozumne.

Lektura katechez pokazuje, że uwaga katechety skupiła się przede wszystkim na ukazaniu pomocy Ducha Świętego względem ludzi, a właściwie na udzieleniu im przeróżnych darów. Słowa biskupa są w tym względzie pełne optymizmu:

Jest jeden wprawdzie Duch Święty, jednego rodzaju i niepodzielny, ale każdemu udziela łaski, jak chce. [...]. Choć jeden jest Duch Święty, sprawia jednak z woli Bożej w imię Chrystusa różne cnoty. U jednego posługuje się językiem ku mądrości, u drugiego oświeca duszę w proroctwie, innemu daje moc wypędzania szatanów, jeszcze innemu udziela daru wykładania Bożego Pisma. Jednego wzmacnia we wstrzemięźliwości, drugiego uczy miłosierdzia, innego postów i umartwienia, jeszcze innego pogardy ziemskich pragnień, lub przygotowuje do męczeństwa ${ }^{57}$.

Ten fragment katechezy jest swobodną parafrazą tekstu z Pierwszego Listu św. Pawła do Koryntian (1 Kor 12,7-11). Cyryl, wskazując katechumenom na różne formy działania Ducha Świętego względem ludzi, zdecydował się przywołać słowa zapisane przez Apostoła Narodów, a więc tym samym powołać się na jego autorytet w tej kwestii. Katechumeni dowiadują się zatem, że i oni mogą stać się adresatami

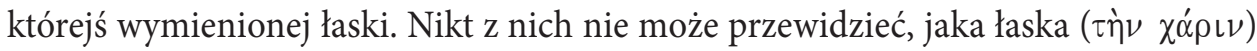
zostanie udzielona podczas chrztu, ponieważ Duch Święty przydziela je, jak chce. Warto ponadto zauważyć obecność trynitarnego kontekstu w powyższym poucze-

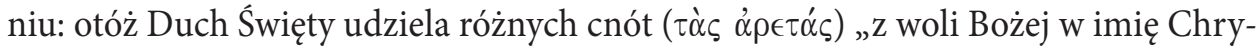

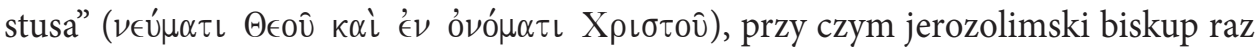
stosuje słowo „łaska”, innym razem „cnota”.

Kolejny passus swej katechezy Cyryl poświęcił duchowi nieczystemu, ukazując jego podstępne zamiary wobec człowieka. Następnie, jakby dla przeciwwagi, wypowiada piękne świadectwo o Duchu Świętym, mówiąc, iż „cała Jego działalność dotyczy dobra i ludzkiego zbawienia. Przede wszystkim łagodne jest Jego przyjście, miłe Jego przyjęcie, bardzo lekkie jarzmo. Jego przyjście poprzedzają promienie światła i wiedzy. Przychodzi z sercem prawdziwego obrońcy. Przychodzi, aby zbawić, leczyć, uczyć, zachęcać, wzmacniać, pocieszać, oświecać duszę, najpierw tego, który Go przyjmuje, a potem przez niego i innych"58. Przytoczony dłuższy cytat zawiera kilka istotnych prawd o Duchu Świętym, stanowiących dla słuchających fundamentalne podstawy wiedzy katechetycznej. Pierwsza z nich podkreśla Jego zbawcze za-

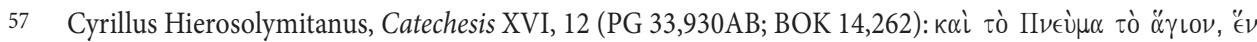

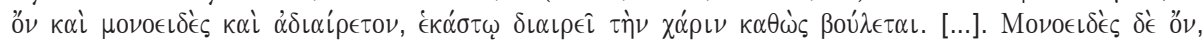

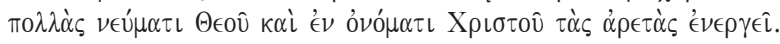

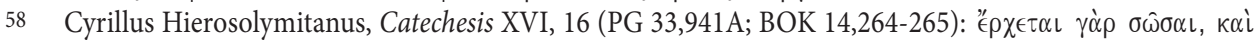

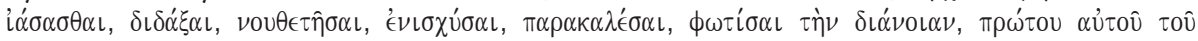

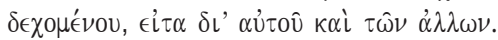


dania wobec ludzi, które polegają na pomnażaniu dobra. Jest ono przeciwstawieniem zła, którego sprawcą jest duch nieczysty. Dlatego zależało biskupowi na wyjaśnieniu różnicy pomiędzy duchem nieczystym a Duchem Świętym. Następna prawda dotyczy Jego sposobu przyjścia do człowieka: jest ono łagodne, miłe, o lekkim jarzmie, poprzedzone promieniami światła i wiedzy, jest On obrońcą z sercem. Nie przychodzi zatem gwałtownie, przejmując mocą duszę człowieka. Owa łagodność przyjścia Ducha Świętego do człowieka łączy się niewątpliwie z otwartością jego serca w oczekiwaniu na dary w postaci konkretnej łaski. Ostatnia prawda ukazuje zaś rozmaite cele Jego przyjścia, które generalnie odnoszą się do wszystkich przyjmujących chrzest. Każdy bowiem może być zbawiony, uleczony, pouczony, zachęcony, wzmocniony, pocieszony, oświecony. Jerozolimski biskup stwierdza nawet, że nowo ochrzczony, doznawszy u siebie tych duchowych wartości, jest w stanie przekazywać je innym ${ }^{59}$.

Dalsze etapy Katechezy XVI są komentarzem do wymienionych prawd, gdzie Cyryl odwołuje się znowu do wydarzeń biblijnych, cytując lub parafrazując różne wątki dotyczące konkretnych osób z dziejów zbawienia. Te biblijne opisy stanowią ilustrację dla katechumenów, jak należy lub nie należy postępować w różnych sytuacjach życiowych. Po tych biblijnych spostrzeżeniach, na zasadzie podsumowania przekazanych katechumenom wiadomości, Cyryl wypowiada następne cechy natury Ducha Świętego: „Kimś wielkim, wszechmocnym w swych darach i dziwnym jest Duch Święty" ${ }^{0}$. Cecha wielkości ( $\mu$ é $\left.\gamma \alpha\right)$ wynika z Jego wszechmocy w dawaniu darów

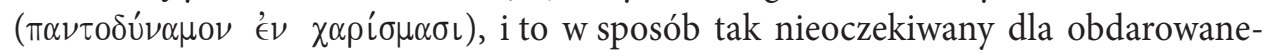

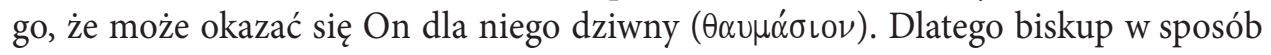
pewny, z dozą dosyć głębokiej zachęty, zwraca się do każdego słuchacza: „I patrz na wielkiego Przewodnika i Dawcę łask. [...]. Widzisz Jego moc, z jaką działa na całym świecie" ${ }^{61}$. Po tych słowach katecheta ukazał szereg sylwetek Starego Testamentu ${ }^{62}$, będących nawiedzonymi przez Ducha Świętego. Poszczególne przykłady zostały przez katechetę krótko skomentowane, co w całości musiało przynieść każdemu słuchaczowi zachętę do podobnych postaw. Jerozolimski katecheta wprowadził bowiem do swojej teologii więcej aspektów kerygmatycznych aniżeli dogmatycznych, nawet w odniesieniu do zbawczych działań Ducha Świętego ${ }^{63}$.

W Katechezie XVII następuje kontynuacja prezentacji osób, które w sposób szczególny doznały łask Ducha Świętego. Są nimi Maryja Dziewica ${ }^{64}$, Elżbieta, Za-

59 Bellido, „Pneumatología de San Cirilo de Jerusalén”, 430.

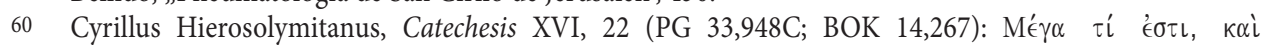

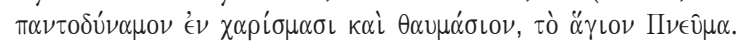

61 Cyrillus Hierosolymitanus, Catechesis XVI, 22-23 (BOK 14,268).

62 Zob. Cyrillus Hierosolymitanus, Catechesis XVI, 24-31 (BOK 14,268-272).

63 Studer, Dio salvatore, 199.

64 Cyrillus Hierosolymitanus, Catechesis XVII, 6 (BOK 14,279): „To tej jest Duch Święty, który przyszedł do świętej Dziewicy". 
chariasz, Symeon ${ }^{65}$, Jan Chrzciciel ${ }^{66}$, Jezus Chrystus ${ }^{67}$, Apostołowie ${ }^{68}$, pierwsi diakoni $^{69}$, św. Pawel ${ }^{70}$. Poszczególne osoby katecheta bliżej opisał, tzn. wymienił czyny, których w mocy Ducha Świętego dokonały one w dziejach zbawienia. Najwięcej komentarza i wyjaśnień poświęcił Jezusowi Chrystusowi, opisując różne formy Jego działalności, począwszy od chrztu w Jordanie. Sporo miejsca zajmuje w tej katechezie przedstawienie znaków zdziałanych przez apostołów.

Na osobną uwagę zasługuje wskazanie działania Ducha Świętego nie tyle w konkretnej osobie, lecz w zgromadzeniu osób, którym jest Kościół katolicki. Słowa biskupa jerozolimskiego są niezwykle wymowne: „Duch Święty - wraz z Ojcem i Synem założywszy Nowe przymierze w Kościele katolickim - uwolnił nas od ciężarów Prawa, mianowicie od przepisów dotyczących tego co czyste i nieczyste, pokarmów, szabatu, nowiu i obrzezania, pokropień i ofiar"71. Mówca wymienił tu te aspekty życia wspólnotowego, które okazują się ciężarem w codzienności, ponieważ należą do Prawa. Rola Ducha Świętego polegała zatem na uwolnieniu od nich członków wspólnoty kościelnej i zastąpieniu ich darami, łaskami oraz cnotami, o których katecheta tylekroć nauczał katechumenów. Te akty Ducha Świętego nastąpiły w nowej

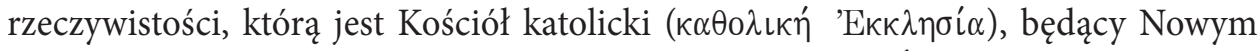

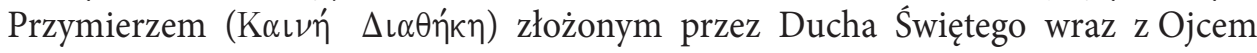

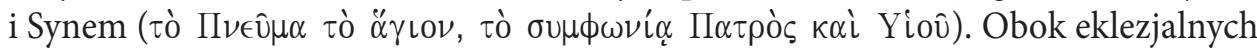
wartości, na które zwraca uwagę Cyryl, nieustannie w jego nauczaniu ma miejsce świadomość przekazu nauki o Duchu Świętym w kontekście trynitarnym. Wprawdzie Cyryl tylekroć odnosił się do poszczególnych Osób Trójcy, niejednokrotnie opisując Ich zadania w ekonomii zbawczej, to jednak nigdy nie wspomniał o boskiej jedności, będącej jedną naturą lub istotą (oủoí $\alpha$ ), ani też nie posłużył się terminem

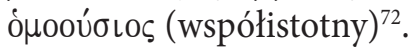

Obok trynitarnego podejścia, któremu poświęcono poprzedni punkt artykułu, Cyryl kilkakrotnie odważył się także wypowiedzieć swoją opinię odnoszącą się do

65 Cyrillus Hierosolymitanus, Catechesis XVII, 7 (BOK 14,280): „Ten Duch Święty działał w Elżbiecie”; „Duchem Świętym napełniony też został ojciec Jana, Zachariasz”; „Ten duch Święty pouczył sprawiedliwego Symeona”.

66 Cyrillus Hierosolymitanus, Catechesis XVII, 8 (BOK 14,280): „Jan, który już w łonie matki napełniony był Duchem Świętym".

67 Cyrillus Hierosolymitanus, Catechesis XVII, 9 (BOK 14,280): „Duch Święty zstąpił w czasie chrztu Pana”.

68 Cyrillus Hierosolymitanus, Catechesis XVII, 12 (BOK 14,282): „Uczestnictwo w Duchu Świętym dał Chrystus Apostołom".

69 Cyrillus Hierosolymitanus, Catechesis XVII, 24 (BOK 14,287-288): „Łaska Ducha Świętego działała nie tylko w dwunastu Apostołach, lecz także w nowo narodzonych dzieciach naszego niegdyś nieurodzajnego Kościoła, mianowicie w siedmiu diakonach".

70 Cyrillus Hierosolymitanus, Catechesis XVII, 26 (BOK 14,288): „Duchem Świętym napełniony został i Paweł, powołany przez Pana naszego Jezusa Chrystusa".

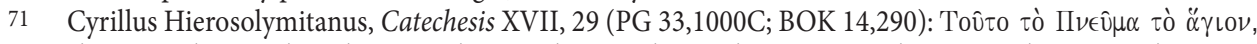

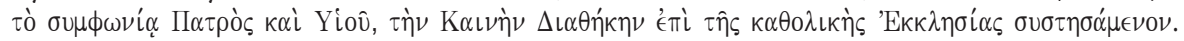

72 Simonetti, La crisi ariana, 208. 
Ducha Świętego jako osoby. Tę teologiczną kwestię porusza w Katechezie XVII. Nawiązując najpierw do aspektu trynitarnego, o Duchu Świętym oznajmia, iż ,jest On Żywy, istnieje osobowo, jest wieczny z Ojcem i Synem, [...], istnieje jako osoba, mówi i działa, udziela łaski i uświęca" "73. Mówca, przypominając zatem o wiecznym istnieniu Ducha Świętego z Ojcem i Synem, dopowiada cechy odnoszące się do Niego, aż dwukrotnie podkreślając Jego osobowe istnienie ${ }^{74}$. W języku greckim zostały tu

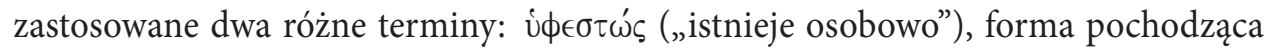

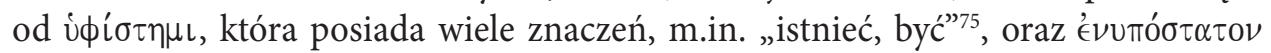

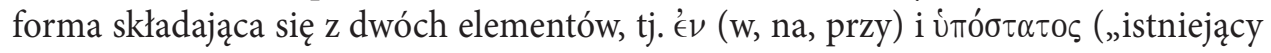
rzeczywiście” $)^{76}$. Polski przekład podkreśla zatem osobowe, rzeczywiste i indywidualne istnienie.

W podobnym tonie te same myśli powtórzył Cyryl przy końcu tejże katechezy, kierując do słuchaczy tego typu przypomnienie: „Że Duch Święty jest osobą, żyje, mówi, przepowiada, powiedzieliśmy już wyżej wiele razy"77. Następnie, w celu uzupełnienia tej myśli, katecheta dodał: „Z tego wszystkiego i z tego, cośmy pominęli, wynika dla każdego myślącego rozumnie - osobowa, uświęcająca i działająca moc Ducha Świętego"78. Wymienione cechy Cyryl zebrał na podstawie wielu przez niego omówionych przykładów działania Ducha Świętego w dziejach zbawienia. Sposób tego działania upoważniał jerozolimskiego biskupa do sformułowania cechy odnoszącej się do natury Ducha Świętego, czyli mocy uświęcającej i działającej.

Okazuje się, że Cyryl, mimo poczynionych zastrzeżeń, zdołał przedstawić słuchaczom naturę Ducha Świętego. Uczynił to, skupiając uwagę na Jego zbawczym działaniu wobec człowieka, gdzie to działanie nazwał konkretną cechą opisującą naturę trzeciej Osoby Boskiej. Obydwie katechezy są bowiem skonstruowane z cytatów biblijnych, dosłownych lub ich parafraz, wraz z komentarzem katechety, aby całość przekazu ukazała całokształt wiedzy dotyczącej Ducha Świętego.

\section{Podsumowanie}

Powyższe analizy tekstów dwóch katechez na temat Ducha Świętego ukazują szerokie spektrum katechumenalnego nauczania Cyryla. Zawarta w tych katechezach

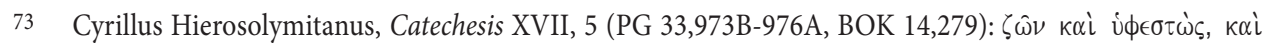

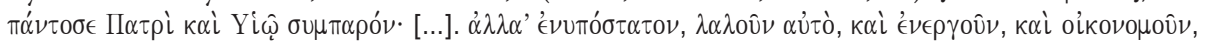

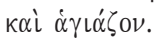

74 Zob. także: Miguel, „Doctrina di San Cirilo de Jerusalén”, 3-63.

75 Zob. Abramowiczówna, Stownik grecko-polski, 482-483.

76 Zob. Abramowiczówna, Stownik grecko-polski, 464.

77 Cyrillus Hierosolymitanus, Catechesis XVII, 33 (BOK 14,292).

78

Cyrillus Hierosolymitanus, Catechesis XVII, 34 (BOK 14,292). 
treść ma jednak charakter jedynie wstępnego zapoznania słuchaczy z nauką o Duchu Świętym, gdyż była kierowana do katechumenów, czyli kandydatów do przyjęcia chrztu. Nie stanowi zatem pogłębionej refleksji teologicznej w formie traktatu katechizmowego lub polemicznego, adresowanego do zaawansowanych znawców zagadnień teologicznych. Należy więc w nauczaniu biskupa jerozolimskiego dostrzec wysoko postawione katechumenom wymogi co do rozpiętości im przekazywanej wiedzy. Ponadto zawartość ideowa i wyjaśnienia teologiczne tych katechez stanowią świadectwo i obraz ówczesnego nauczania pasterskiego, a struktura ich treści ukazuje umiejętności pedagogiczne biskupa Jerozolimy. Podkreślić należy także biblijny charakter ukazania słuchaczom tego trudnego zagadnienia, jakim jest opisanie Ducha Świętego. Oparcie się na tekstach Pisma Świętego charakteryzuje bowiem przekaz wszystkich katechez Cyryla, co powoduje, że nie udziela on błędnych informacji, a zwłaszcza nie głosi swoich osobistych interpretacji. Analiza treści tych katechez wykazuje również na osobiste zaangażowanie w przekaz poprawnej nauki katolickiej, co zostało przez niego ukazane poprzez ostrą konfrontację z błędnowiercami i jednocześnie ostrzeżenie słuchaczy przed popadnięciem w wadliwe zasady wiary chrześcijańskiej.

\section{Bibliografia}

\section{Źródła}

Basilius, De Spiritu Sancto (red. B. Pruche) (SCh 17 bis; Paris 1968), tłum. A. Brzóstkowska: Św. Bazyli Wielki, O Duchu Świętym (Warszawa: Instytut Wydawniczy Pax 1999).

Cyrillus Hierosolymitanus, Catechesis XVI (PG 33,917-966), tłum. W. Kania: Św. Cyryl Jerozolimski, Katechezy przedchrzcielne i mistagogiczne, BOK 14 (Kraków: Wydawnictwo „M” 2000) 257-275.

Cyrillus Hierosolymitanus, Catechesis XVII (PG 33, 967-1012), tłum. W. Kania: Św. Cyryl Jerozolimski, Katechezy przedchrzcielne i mistagogiczne, BOK 14 (Kraków: Wydawnictwo „M” 2000), 277-298.

„Wyznanie wiary 150 Ojców”, Dokumenty Soborów Powszechnych (red. A. Baron - H. Pietras) (Źródła Myśli Teologicznej 24; Kraków: WAM 2001) I, 68-69.

„Wyznanie wiary 318 Ojców”, Dokumenty Soborów Powszechnych (red. A. Baron - H. Pietras) (Źródła Myśli Teologicznej 24; Kraków: WAM 2001) I, 24-25.

\section{Opracowania}

Abramowiczówna, Z., Słownik grecko-polski (Warszawa: Państwowe Wydawnictwo Naukowe 1965) IV.

Altaner, A. - Stuiber, A., Patrologia. Życie, pisma i nauka Ojców Kościoła (tłum. P. Pachciarek) (Warszawa: Instytut Wydawniczy Pax 1990).

Andresen, C., „Zur Entstehung und Geschichte des Trinitarischen Personenbegriffes”, Zeitschrift für die neutestamentliche Wissenschaft 52 (1961) 1-39. 


\section{NORBERT WIDOK}

Aranda, A., „El Espíritu Santo en los Símbolos de Cirilo de Jerusalén y Alejandro de Alejadría”, Scripta Theologica 5 (1973) 223-278.

Bellido, C.G., „Pneumatología de San Cirilo de Jerusalén”, Estudios eclesiásticos 58 (1983) 421-490.

Bonato, A., La dottrina trinitaria di Cirillo di Gerusalemme (Studia Ephemeridis Augustinianum 18; Roma: Institutum Patristicum „Augustinianum” 1983).

Calisi, A., Lo Spirito Santo in Cirillo di Gerusalemme (Bari: Chàrisma 2013).

Carpenter, H.J., „Creeds and Baptismal Rites in the First Four Centuries”, The Journal of Theological Studies 44 (1943) 1-11.

Congar, Y., Wierzę w Ducha Świętego (Warszawa: Wydawnictwo Księży Marianów 1995) I.

Crehan, J.H., Early Christian Baptism and the Creed: A Study in Ante-Nicene Theology (London: Burns, Oates \& Washbourne 1950).

Daniélou, J., La catechesi nei primi secoli (Torino: Elle Di Ci 1982).

Day, J., „Lent and the Catechetical Program in mid-fourth-century Jerusalem”, Studia liturgica 35 (2005) 129-147.

Fiedrowicz, M., Teologia ojców Kościoła. Podstawy wczesnochrześcijańskiej refleksji nad wiara (Kraków: Wydawnictwo Uniwersytetu Jagiellońskiego 2009).

Gryglewicz, F., „Jan Ewangelista o Duchu Świętym w Kościele”, Duch Święty - Duch Boży (red. L. Stachowiak - R. Rubinkiewicz) (Materiały Pomocnicze do Wykładów z Biblistyki 7; Lublin: Redakcja Wydawnictw KUL 1985) 89-100.

Gryglewicz, F., Jezusowe przemówienia w czwartej Ewangelii (Kraków: Polskie Towarzystwo Teologiczne 1986).

Guillet, J., „Duch Boży”, Słownik teologii biblijnej (red. X. Leon-Dufour; tłum. K. Romaniuk) (Poznań - Warszawa: Pallotinum 1982) 226-235.

de Halleux, A., „ «Hypostase» et «personne» dans la formation du dogme trinitaire (ca 375-381)”, Revue d histoire ecclésiastique 79/1 (1984) 313-369; 79/3-4 (1984) 625-670.

Hamman, A., Portrety Ojców Kościoła (tłum. zbiorowe) (Warszawa: Instytut Wydawniczy Pax 1978).

Jankowski, A., Zarys pneumatologii Nowego Testamentu (Kraków: Polskie Towarzystwo Teologiczne 1982).

Kalleres, D.S., „Cultivating True Sight at the Center of the World: Cyril of Jerusalem and the Lenten Catechumenate", Church History 74 (2005) 431-459.

Kania, W., „Istotne cechy katechezy św. Cyryla Jerozolimskiego”, Vox Patrum 10/18 (1990) 75-81.

Kelly, J.N.D., Początki doktryny chrześcijańskiej (Warszawa: Instytut Wydawniczy Pax 1988).

Maggioni, B., „I simboli della fede delle prime comunità cristiane”, Revue philosophique de Louvain 4 (1979) 9-13.

Miguel, J.L.F., „Doctrina di San Cirilo de Jerusalén sobre el Espíritu Santo”, Studium 14 (1974) 3-63.

Paczkowski, C.M., „Teologia świadectwa i doświadczenia w Katechezach Cyryla Jerozlimskiego", Quaestiones Selectae 8 (2001) 51-73.

Pietras, H., „Geneza Symbolu Apostolskiego”, Symbol Apostolski w nauczaniu i sztuce Kościoła (red. R. Knapiński) (Lublin: TN KUL 1997) 63-76.

Quasten, J., Patrologia. I Padri greci (secoli IV-V) (Casale Monferrato: Marietti 1983) II. 
Sesboüé, B. - Wolinski, J., Bóg zbawienia (Historia Dogmatów 1; tłum. P. Rak, Kraków: Wydawnictwo „M” 1999).

Simonetti, M., La crisi ariana nel IV secolo (Roma: Institutum Patristicum „Augustinianum” 1975).

Stephenson, A.A, „Cyril of Jerusalem and the Alexandrian Heritage”, Theological Studies 15 (1954) 573-593.

Stephenson, A.A, „Saint Cyril Trinitarian Theology”, Studia Patristica 11 (1972) 234-241.

Studer, B., „Triteismo”, Dizionario patristico e di antichità cristiane (red. A. Di Berardino) (Casale Monferrato: Marietti 1983) II.

Studer, B., Dio salvatore nei Padri della chiesa (Roma: Borla 1986).

Widok, N., „Polemika antyheretycka w Katechezach Cyryla Jerozolimskiego”, Vox Patrum 37/68 (2017) 423-442. 
